\title{
PAKOM PELATIHAN DAN PENDAMPINGAN PENYUSUNAN PERANGKAT PEMBELAJARAN MATEMATIKA BERBASIS LESSON STUDY
}

\author{
Rita Pramujiyanti Khotimah, Masduki, N. Setyaningsih \\ Pendidikan Matematika \\ Fakultas Keguruan dan Ilmu Pendidikan \\ Unversitas Muhammadiyah Surakarta \\ Email: rpramujiyanti@ums.ac.id,masduki@ums.ac.id,ningsetya@ums.ac.id
}

\begin{abstract}
ABSTRAK
Guru yang profesional adalah salah satu faktor penentu keberhasilan proses belajar mengajar di kelas. Kemampuan merancang perangkat pembelajaran yang berkualitas menunjukkan kesiapan guru dalam mengajar. Tujuan dari kegiatan ini untuk meningkatkan kemampuan guru matematika SMA/SMK Muhamamadiyah Klaten dalam mengembangkan Rencana Pelaksanaan Pembelajaran (RPP) melalui pendekatan lesson study. Metode pelaksanaan melalui Sosialisasi, pelatihan dan pendampingan. Hasil pelaksanaan kegiatan: (1) Ada peningkatan kemampuan guruguru matematika di SMA/SMK Muhammadiyah Klaten dalam hal mengembangkan perangkat pembelajaran matematika berbasis lesson study. (2) Respon peserta terhadap pelaksanaan kegiatan sangat baik.
\end{abstract}

Kata kunci: guru, RPP, Lesson Study

\begin{abstract}
Professional teachers is one of a factor determining the success of teaching and learning in the classroom. The ability to design quality learning device indicates the readiness of teachers in teaching. The purpose of this activity is to improve the ability of mathematics teachers in developing lesson plan in SMA/SMK Muhammadiyah Klaten through Lesson Study approach. The method of implementation through socialization, training and companionship. The results of the implementation of activities:(1) There is an increasing of the ability of mathematics teachers in SMA/ SMK Muhammadiyah Klaten on developing lesson plan based Lesson Study. (2) The response of participants on the implementation of activities very well.
\end{abstract}

Keywords: teachers, lesson plans, Lesson Study

\section{Pendahuluan}

Berdasarkan UU Guru dan Dosen No. 14 Th 2005 Pasal 10 ayat 1 Tentang Kompetensi guru, seorang guru yang professional harus memiliki empat macam kompetensi, yaitu kompetensi pedagogik, kompetensi kepribadian, kompetensi professional, dan kompetensi sosial. Banyak cara yang dapat dilakukan oleh guru untuk bisa meningkatkan keempat kompetensi tersebut.
Salah satu diantaranya adalah dengan belajar pengalaman guru lain. Belajar pengalaman guru lain dapat dilaksanakan melalui Lesson Study. Lesson Study merupakan salah satu model pembinaan profesi pendidik melalui pengkajian pembelajaran secara kolaboratif dan berkelanjutan berlandaskan pada prinsipprinsip kolegalitas dan mutual learning untuk membangun komunitas belajar (Mulyana, 2007). Lesson Study merupakan kegiatan 
yang dapat mendorong terbentuknya sebuah komunitas belajar (learning society) yang secara konsisten dan sistematis melakukan perbaikan diri, baik pada tataran individual maupun manajerial.

Pada awalnya, Lesson Study hanya dilaksanakan pada pendidikan dasar, namun dalam perkembangannya, Lesson Study juga banyak diterapkan di Perguruan Tinggi. Sukirman (2010) menyebutkan bahwa Lesson Study mempunyai beberapa manfaat: (1) Mengurangi keterasingan dosen dalam perencanaan dan pelaksanaan pembelajaran dan perbaikannya. (2) Membantu pendidik untuk mengobservasi dan mengkritisi pembelajarannya. (3) Memperdalam pemahaman pendidik tentang materi pelajaran, cakupan dan urutan kurikulum. (4) Membantu pendidik memfokuskan bantuannya pada seluruh aktivitas belajar mahasiswa. (5) Meningkatkan akuntabilitas kinerja dosen. (6) Menciptakan terjadinya pertukaran pemahaman tentang cara berfikir dan belajar mahasiswa. (7) Meningkatkan kolaborasi pada sesama pendidik dalam pembelajaran. (8) Meningkatkan mutu pendidik dan mutu pembelajaran yang pada gilirannya berakibat pada peningkatan mutu lulusan. (9) Pendidik memiliki banyak kesempatan untuk membuat bermakna ide-ide pendidikan dalam praktek pembelajarannya sehingga dapat mengubah perspektif tentang pembelajaran, dan belajar praktek pembelajaran dari perspektif mahasiswa. (10) Memperbaiki praktek pembelajaran di kelas. (11) Meningkatkan ketrampilan menulis karya ilmiah atau buku ajar. Pelaksanaan Lesson Study menggunakan sistem siklus, di mana setiap siklus dilaksanakan dalam 3 tahap yaitu (1) perencanaan (plan), (2) pelaksanaan $(d o)$, (3) Refleksi (See).

SMA Muhammadiyah 1 dan SMK Muhammadiyah 1 Klaten adalah sekolahsekolah sasaran pengabdian pada masyarakat yang dilaksanakan oleh tim dosen Program Studi Pendidikan Matematika FKIP UMS. Permasalahan guru matematika di SMA Muhammadiyah 1 dan SMK Muhammadiyah
1 Klaten terkait dengan kompetensi pedagogik guru adalah masih lemahnya kemampuan dalam mengembangkan perangkat pembelajaran matematika. Berdasarkan hasil wawancara dengan guru-guru matematika pada saat dilaksanakan pengabdian pada masyarakat tahun 2014, diperoleh informasi bahwa guru umumnya hanya menggunakan Rencana Pelaksanaan Pembelajaran (RPP) yang telah dikembangkan oleh Diknas atau MGMP matematika. Guru juga belum mampu mengembangkan perangkat pembelajaran yang inovatif yang dapat menumbuhkan suasana pembelajaran yang menyenangkan serta mampu mengembangkan semua potensi yang dimiliki peserta didik. Mayoritas guru menganggap bahwa metode ceramah merupakan metode yang paling efektif untuk mengajarkan matematika. Guru jarang mengembangkan dan menggunakan lembar kerja siswa dan media dalam pelaksanaan pembelajaran. Guru umumnya menggunakan LKS yang dikembangkan oleh para penerbit. Dengan kata lain, guru-guru matematika di SMA dan SMK Muhammadiyah 1 Klaten hanya menggunakan perangkat pembelajaran yang sudah jadi dan jarang berusaha mengembangkan sesuai dengan kebutuhan di sekolah.

Berdasarkan uraian pada analisis situasi dan dari studi awal yang dilakukan tim pengabdian, maka dapat diidentifikasi permasalahan yang dihadapi mitra yaitu guru-guru matematika SMAMuhammadiyah 1 dan SMK Muhammadiyah 1 Klaten kaitannya dengan pengembangan profesi guru adalah sebagai berikut: 1) kurangnya kemampuan guru dalam pengembangan perangkat pembelajaran yang berkualitas, 2) kurangnya kemampuan guru dalam pengembangan media pembelajaran dan instrumen penilaian hasil pembelajaran yang berkualitas, 3) kurangnya kemampuan guru dalam penguasaan konsep materi keilmuan yang relevan, 4) hasil-hasil pelatihan guru yang sudah pernah dilakukan belum diimplementasikan dengan baik oleh guru untuk meningkatkan kualitas pembelajaran di kelas, 5) belum dikembangkannya 
prinsip kolaborasi dalam pengembangan profesionalisme guru melalui lesson study.

Adapun perumusan masalah dalam kegiatan ini adalah bagaimana meningkatkan kemampuan guru matematika dalam mengembangkan perangkat pembelajaran (RPP) di SMA Muhammadiyah 1 dan SMK Muhammadiyah 1 Klaten melalui pendekatan lesson study. Subadi, Khotimah, dan Sutarni (2012, 2013) telah mengadakan kegiatan penelitian dalamrangkapengembanganmodel pendidik profesional bagi guru-guru sekolah Muhammadiyah di Kabupaten Sukoharjo. Hasil penelitian menunjukkan bahwa: 1) terjadi peningkatan cukup signifikan pada kompetensi guru indikatornya perangkat pembelajaran menjadi lebih lengkap, penguasaan IT lebih meningkat, pemilihan metode dan strategi pembelajaran lebih tepat. Karena itu pembinaan guru dengan pendekatan Lesson Study perlu adanya keberlanjutan, 2) model pembelajaran aktif, inovatif, kreatif, efektif, dan menyenangkan dalam Lesson Study adalah "model pembelajaran berbasis kolaboratif dan kooperatif" sedangkan efektifitas Lesson Study sebagai model pembinaan guru adalah Lesson Study berbasis MGMP (Musyawarah Guru Mata Pelajaran) implementasinya oleh guru model di sekolah masing-masing.

Slamet, Khotimah (2010) juga menyimpulkan setelah pelaksanaan pendampingan Lesson Study: 1) ditinjau dari penguasaan materi, guru mengalami peningkatan pemahaman terutama pada operasi bilangan pecahan dan konsep luas bangun-bangun datar yang semula dipandang sebagai sebuah kesulitan untuk mengajarkannya kepada siswa, 2) guru-guru mengalami peningkatan profesionalisme terutama dalam menyusun RPP. RPP adalah perangkat utama pembelajaran, oleh karena itu dengan kesempurnaan RPP sebagai indikator proses belajar mengajar akan berjalan dengan baik dan ujung-ujngnya akan dapat meningkatkan prestasi belajar siswa.

Tujuan pelaksanaan kegiatan ini untuk meningkatkan kemampuan guru matematika dalam mengembangkan Rencana
Pelaksanaan Pembelajaran (RPP) di SMA Muhammadiyah 1 dan SMK Muhammadiyah 1 Klaten melalui pendekatan Lesson Study. Manfaat kegiatan bagi guru adalah dapat meningkatkan kemampuan profesionalisme guru terutama dalam hal perencanaan, pelaksanaan dan evaluasi pembelajaran.

\section{Metode Pelaksanaan}

Kegiatan pengabdian masyarakat ini dilakukan dalam dua tahap, yaitu tahap sosialisasi Lesson Study dalam bentuk ceramah dan tahap workshop Lesson Study dalam bentuk pendampingan . Pada tahap pertama, guru diberikan penjelasan tentang pentingnya model Lesson Study sebagai salah satu upaya untuk mengembangkan kemampuan profesional, pedagogis, dan prinsip kolegialitas dalam peningkatan kualitas pembelajaran. Tahap berikutnya adalah workshop Lesson Study, yang meliputi kegiatan: (1) Identifikasi masalah pembelajaran yang ada di kelas yang akan digunakan untuk kegiatan Lesson Study, dan perencanaan alternatif pemecahannya. Identifikasi masalah tersebut berkaitan dengan pokok bahasan (materi pelajaran) yang relevan, karakteristik siswa dan suasana kelas, metode/pendekatan pembelajaran, media/alat peraga, dan proses evaluasi dan hasil belajar yang akan dicapai; (2) Dari hasil identifikasi masalah dan diskusi perencanaan pemecahannya, selanjutnya disusun dan dikemas dalam suatu perangkat pembelajaran yang terdiri atas: (a) Rencana Pelaksanaan Pembelajaran (RPP), (b) Materi ajar, (c) Lembar Kerja Siswa (LKS) / Media pembelajaran, (d) Instrumen penilaian proses dan hasil pembelajaran, dan (f) Lembar observasi pembelajaran.

\section{Hasil dan Pembahasan}

Kegiatan ini telah dilaksanakan dalam dua tahap. Tahap pertama adalah sosialisasi Lesson Study, dan tahap kedua workshop Lesson Study (pengembangan perangkat pembelajaran berbasis Lesson Study). Peserta kegiatan ini adalah guru-guru matematika tingkat SMA/SMK se Kabupaten Klaten. 
Semua kegiatan dilaksanakan di SMA Muhammadiyah 1 Klaten. Tahap pertama dilaksanakan pada hari Sabtu, 23 April 2016. Tahap kedua hari Rabu, tanggal 18 Mei 2016 dan Sabtu, 10 September 2016. Secara rinci masing-masing kegiatan dapat diuraikan sebagai berikut:

\section{a. Tahap Pertama: Sosialisasi Lesson Study}

Kegiatan sosialisasi Lesson Study bagi gurumatematikaSMA/SMK Muhammadiyah di Kabupaten Klaten dilaksanakan pada hari Sabtu, 23 April 2016 bertempat di SMA Muhammadiyah I Klaten. Kegiatan ini diikuti oleh 33 orang guru matematika SMA/ SMK Muhammadiyah di Klaten dan dihadiri oleh pengurus Musyawarah Kerja Kepala Sekolah (MKKS) SLTA Muhammadiyah di Klaten sekaligus Kepala Sekolah SMK Muhammadiyah 3 Klaten. Tahap pertama kegiatan dilaksanakan secara Tim dan menghadirkan Narasumber Pengembangan Keprofesian Berkelanjutan (PKB) yaitu Drs. Muhroji, M.Si, dosen program studi Pendidikan Guru Sekolah Dasar (PGSD) UMS yang merupakan salah satu pengelola program Pendidikan dan Latihan Profesi Guru (PLPG) di UMS. Pada awal pertemuan ini, narasumber menyampaikan tentang pentingnya pengembangan keprofesian berkelanjutan bagi guru-guru.

Pengembangan keprofesian berkelanjutan adalah pengembangan kompetensi guru yang dilaksanakan sesuai dengan kebutuhan, bertahap dan berkelanjutan untuk meningkatkan profesionalitasnya (Permenegpan dan RB No. 16 Tahun 2009 Pasal 1 butir 5). PKB sendiri ada tiga macam yaitu: 1) pengembangan diri, meliputi: diklat fungsional dan kegiatan kolektif guru, 2) publikasi ilmiah dengan jenis kegiatan: presentasi pada forum ilmiah, publikasi ilmiah atas hasil penelitian atau gagasan ilmu di bidang pendidikan formal, publikasi buku pelajaran, buku pengayaan, dan pedoman guru, dan 3) karya inovatif, meliputi: menemukan teknologi tepat guna, menemukan/menciptakan karya seni, membuat/memodifikasialat pelajaran/peraga/ praktikum, dan mengikuti pengembangan penyusunan standar, pedoman, soal dan sejenisnya. Setelah pemaparan materi tentang PKB ini berakhir, dilanjutkan dengan sesi tanya jawab/diskusi tentang PKB antar peserta dengan narasumber sehingga peserta dapat semakin memahami pentingnya PKB bagi guru untuk meningkatkan kemampuan profesionalisme yang dimilikinya.

Kegiatan selanjutnya adalah sosialisasi Lesson Study sebagai salah satu bentuk aktivitas/kegiatan kolektif guru dalam PKB. Materi Lesson Study dipaparkan ketua Tim Pengabdian. Pada sesi ini, materi Lesson Study yang disampaikan adalah tentang: 1) mengapa perlu ada Lesson Study, 2) apa itu Lesson Study, dan 3) bagaimana cara melaksanakan Lesson Study. Manfaat dengan adanya pelaksanaan Lesson Study di antaranya: 1) dapat mengembangkan keahlian mengajar guru/dosen, 2) membangun kemampuan kolegalitas guru/dosen dalam mengajar sehingga guru/dosen bisa lebih terbuka terhadap kritik/saran dari guru/ dosen lain, 3) mengembangkan "The Eyes to See Students", dan, 4) guru/dosen dapat mendokumentasikan kemajuan kerjanya sebagai karya ilmiah guru/dosen (dalam bentuk laporan penelitian/artikel publikasi).

Selanjutnya juga dipaparkan tentang bagaimana seorang guru/dosen bisa melaksanakan Lesson Study, yaitu melalui tahapan-tahapan plan-do-see. Plan diawali dengan kegiatan menganalisis kebutuhan dan permasalahan yang dihadapi dalam pembelajaran,menentukanguru/dosenmodel, dan menyusun perangkat pembelajaran (RPP) lengkap beserta lampirannya yang mencerminkan pembelajaran yang berpusat pada siswa. Dalam tahap do, guru/dosen model melaksanakan pembelajaran sesuai dengan rencana pembelajaran yang telah disusun bersama-sama. Pada saat tindakan dilaksanakan, ada observer yang melakukan pengamatan terhadap seluruh proses pembelajaran yaitu terhadap tindak mengajar guru/dosen dan tindak belajar siswa/ mahasiswa. Tahap terakhir dalam Lesson Study adalah see/refleksi. Kegiatan see dilakukan dalam bentuk diskusi, dimulai dari 
penyampaian kesan-kesan guru yang telah mempraktikkan pembelajaran, dilanjutkan dengan pemberian tanggapan perwakilan guru yang terlibat dalam pengembangan perangkat pembelajaran, tanggapantanggapan observer lain,atau komentar dari tenaga ahli (dosen jika ada), dan pemberian simpulan untuk perbaikan pada putaran berikutnya.

Setelah penyampaian materi Lesson Study, selanjutnya peserta diberikan waktu khusus untuk berdiskusi/tanya jawab. Banyak pertanyaan yang diajukan oleh peserta terkait dengan Lesson Study ini, di antaranya adalah: apakah sama antara observer pada pelaksanaan Lesson Study dengan supervisi? apakah yang menjadi observer harus sesama guru mata pelajaran? Karena Lesson Study adalah kerja kolaboratif dengan teman sejawat, bagaimana mengatasi kendala kesulitan membentuk kelompok/ Tim Lesson Study? dsb.

Tahap pertama ini diakhiri dengan pembentukan Tim Lesson Study. Tim Lesson Study yang dibentuk diupayakan berasal dari satu sekolah yang sama atau apabila sekolahnya berbeda, dipilih sekolah yang berdekatan. Setelah tim terbentuk, selanjutnya dilakukan brainstorming peserta untuk mengidentifikasi permasalahanpermasalahan riil yang dijumpai dalam pembelajaran matematika di sekolah masingmasing dan dicari semua akar penyebab masalahnya. Akar penyebab masalah yang dominan akan menjadi dasar bagi masingmasing tim untuk mencari alternatif tindakan perbaikan. Alternatif tindakan yang telah disepakati, selanjutnya disusun dalam bentuk perencanaan pembelajaran (Rencana Pelaksanaan Pembelajaran/RPP) yang berbasis Lesson Study.

\section{b. Tahap Kedua: Workshop Lesson Study}

Tahap kedua dilaksanakan dalam dua pertemuan, yakni pada hari Rabu, 18 Mei 2016 dan Sabtu, 10 September 2016 bertempat di SMA Muhammadiyah I Klaten. Pertemuan kedua tahap kedua ini dihadiri oleh 32 orang guru matematika SMA/SMK
Muhammadiyah di Klaten. Pada pertemuan ini, kegiatan yang dilaksanakan adalah pendampingan penyusunan perangkat pembelajaran/RPP. Karena semua sekolah masih menerapkan Kurikulum KTSP, belum Kurikulum 2013, maka komponenkomponen RPP yang dikembangkan oleh peserta meliputi: identitas sekolah, standar kompetensi, kompetensi dasar, indikator, tujuan pembelajaran, materi ajar, model/ strategi pembelajaran, langkah-langkah kegiatan pembelajaran, alat/media, sumber belajar, dan penilaian.

Kegiatan pada pertemuan kedua tahap kedua masih belum bisa berjalan dengan optimal karena masih banyak kelompok peserta pengabdian yang kesulitan dalam menyusun indikator dan tujuan pembelajaran serta merumuskan langkah-langkah pembelajaran berdasarkan pemilihan model/ strateginya. Dalam merumuskan indikator pembelajaran masih banyak yang belum menggunakan kata kerja operasional, ada yang menggunakan 2 kata kerja, indikator yang dirumuskan juga ada yang belum sesuai dengan alokasi waktu. Untuk rumusan tujuan, permasalahan yang muncul ada yang belum mengacu pada indikator, ada yang merumuskan tujuan hanya memperhatikan hasil (tidak memperhatikan proses), tujuan yang dirumuskan ada yang lebih sedikit daripada indikator.

Pelaksanaan kegiatan tahap kedua dilanjutkan pada pertemuan kedua, yaitu pada hari Sabtu, 10 September 2016. Pertemuan kedua ini juga bertempat di SMA Muhammadiyah 1 Klaten. Karena bersamaan dengan pelaksanaan akreditasi di beberapa sekolah, pertemuan kedua ini hanya dihadiri oleh 21 peserta pengabdian. Supaya lebih efisien, pada pertemuan ini peserta pengabdian dibagi menjadi 2 kelompok besar. Pada masing-masing kelompok, dilaksanakan presentasi/pemaparan RPP yang telah dikembangkan pada pertemuan sebelumnya. Melalui presentasi ini, masingmasing tim sekolah bisa membandingkan RPP yang telah dibuat dengan RPP tim sekolah lain, juga bisa melihat kelebihan dan 
kekurangan dari RPP masing-masing.

Pada pertemuan ini, narasumber juga memberikan ulasan/review terhadap hasil kerja masing-masing tim sekolah dalam menyusun RPP. Narasumber kembali memberikan penegasan pada peserta tentang hal-hal apa saja yang diperlukan dalam menyusun perangkat pembelajaran, mulai dari penulisan identitas sekolah, standar kompetensi, kompetensi dasar, perumusan indikator, tujuan pembelajaran, materi ajar, model/strategi pembelajaran, langkahlangkah kegiatan pembelajaran, alat/media, sumber belajar dan penilaian, serta lampiranlampiran apa saja yang perlu ada di dalam perangkat pembelajaran. Masing-masing kelompok selanjutnya dibimbing untuk melakukan perbaikan perangkat yang telah disusun.

Hasil kegiatan pada pertemuan kedua sudah lebih baik daripada hasil pada pertemuan sebelumnya, hal ini tampak pada hasil perbaikan RPP dari masing-masing kelompok untuk masing-masing komponen RPP sebagaimana dapat dilihat pada Tabel 1.

Tabel 1. Isi RPP Sebelum dan Sesudah Pelatihan

\begin{tabular}{|c|c|c|c|}
\hline No & Komponen RPP & Sebelum & Sesudah \\
\hline 1 & Identitas Sekolah & $\begin{array}{l}\text { 57,14\% kelompok menuliskan } \\
\text { identitas sekolah di RPP. } \\
\text { Kelompok yang sudah } \\
\text { menuliskan identitas, belum } \\
\text { sepenuhnya benar/belum } \\
\text { lengkap. }\end{array}$ & $\begin{array}{l}100 \% \text { kelompok menuliskan } \\
\text { identitas sekolah di RPP dengan } \\
\text { benar/lengkap. }\end{array}$ \\
\hline 2 & Standar Kompetensi & $\begin{array}{l}\text { Sudah ada } 100 \% \text { di semua RPP } \\
\text { yang disusun dengan benar. }\end{array}$ & $\begin{array}{l}\text { Sudah ada } 100 \% \text { di semua RPP yang } \\
\text { disusun dengan benar. }\end{array}$ \\
\hline 3 & Kompetensi Dasar & $\begin{array}{l}\text { Sudah ada } 100 \% \text { di semua RPP } \\
\text { yang disusun dengan benar. }\end{array}$ & $\begin{array}{l}\text { Sudah ada } 100 \% \text { di semua RPP yang } \\
\text { disusun dengan benar. }\end{array}$ \\
\hline 4 & Indikator & $\begin{array}{l}\text { Hanya } 42,85 \% \text { kelompok } \\
\text { yang merumuskan indikator } \\
\text { pembelajaran dengan tepat. }\end{array}$ & $\begin{array}{l}85,71 \% \text { kelompok sudah } \\
\text { merumuskan indikator pembelajaran } \\
\text { dengan tepat. Hal ini terlihat dari } \\
\text { perumusan indikator yang sudah } \\
\text { sesuai dengan kompetensi dasar, } \\
\text { penggunaan kata kerja yang sudah } \\
\text { operasional, dan satu indikator } \\
\text { hanya menggunakan satu kata kerja } \\
\text { operasional. }\end{array}$ \\
\hline 5 & $\begin{array}{l}\text { Tujuan } \\
\text { Pembelajaran }\end{array}$ & $\begin{array}{l}\text { Hanya } 42,85 \% \text { kelompok } \\
\text { yang merumuskan tujuan } \\
\text { pembelajaran dengan tepat. }\end{array}$ & $\begin{array}{l}71,42 \% \text { kelompok sudah } \\
\text { merumuskan tujuan pembelajaran } \\
\text { dengan tepat. Tujuan yang } \\
\text { dirumuskan sudah mengacu } \\
\text { pada indikator, dalam perumusan } \\
\text { tujuan juga sudah banyak } \\
\text { yang memperhatikan proses } \\
\text { pembelajaran, tidak hanya sekedar } \\
\text { hasil saja. }\end{array}$ \\
\hline 6 & Model/Strategi & $\begin{array}{l}\text { Hanya } 42,85 \% \text { kelompok } \\
\text { yang pemilihan model/strategi } \\
\text { pembelajarannya sudah tepat. }\end{array}$ & $\begin{array}{l}85,71 \% \text { kelompok telah memilih } \\
\text { model/strategi pembelajaran yang } \\
\text { tepat. Langkah-langkah penerapan } \\
\text { strategi sudah terlihat dalam } \\
\text { kegiatan inti pembelajaran. }\end{array}$ \\
\hline
\end{tabular}




\begin{tabular}{|c|c|c|c|}
\hline 7 & Materi Ajar & $\begin{array}{l}57,14 \% \text { kelompok dalam } \\
\text { pengembangan materi ajar sudah } \\
\text { tepat, ada yang belum sesuai } \\
\text { dengan indikator dan alokasi } \\
\text { waktu. }\end{array}$ & $\begin{array}{l}85,71 \% \text { pemilihan materi ajar sudah } \\
\text { tepat, sudah sesuai dengan indikator } \\
\text { pembelajaran dan alokasi waktu. }\end{array}$ \\
\hline 8 & Alat/Media & $\begin{array}{l}\text { Sebanyak 28,57\% kelompok } \\
\text { belum mengembangkan alat/ } \\
\text { media pembelajaran dengan tepat. }\end{array}$ & $\begin{array}{l}71,42 \% \text { kelompok sudah } \\
\text { mengembangkan alat/media pada } \\
\text { RPP, yang relevan dengan materi } \\
\text { pembelajaran. }\end{array}$ \\
\hline 9 & Sumber Belajar & $\begin{array}{ll}57,14 \% & \text { kelompok dalam } \\
\text { menuliskan } & \text { sumber belajar sudah } \\
\text { benar. } & \\
\end{array}$ & $\begin{array}{l}85,71 \% \text { kelompok dalam menuliskan } \\
\text { sumber belajar sudah benar. }\end{array}$ \\
\hline 10 & Penilaian & $\begin{array}{l}42,75 \% \text { kelompok dalam } \\
\text { penilaian yang dikembangkan } \\
\text { sudah mengukur indikator } \\
\text { pembelajaran dengan tepat. }\end{array}$ & $\begin{array}{l}85,71 \% \% \text { kelompok dalam penilaian } \\
\text { yang dikembangkan sudah mengukur } \\
\text { indikator pembelajaran dengan } \\
\text { tepat, sudah dilengapi dengan kunci } \\
\text { jawaban dan pedoman penskoran. }\end{array}$ \\
\hline
\end{tabular}

Berdasarkan hasil pelaksanaan kegiatan tahap akhir, nampak bahwa ada peningkatan kemampuan guru dalam pengembangan perangkat pembelajaran (RPP), penguasaan konsep materi pengetahuan/materi ajar, dan pengembangan instrument penilaian pembelajaran. Hal ini terlihat dari hasil perbaikan masing-masing komponen RPP yang disusun oleh masing-masing kelompok sebagaimana Tabel 1.

Respon peserta selama kegiatan berlangsung, sangat baik. Hal ini terlihat berdasarkan hasil pengamatan selama pelaksanaan pendampingan, baik pada tahap pertama maupun kedua. Peserta terlihat semangat dan antusias dalam mengikuti kegiatan, terbukti dari banyaknya kehadiran peserta dalam setiap pertemuan dan peserta terlihat aktif pada saat diskusi. Selain itu antusiasme peserta juga dapat dilihat dari hasil angket respon yang diberikan. Hasil kegiatan ini sejalan dengan Muamaroh (2015) yang menyatakan bahwa, peserta pengabdian bisa meningkatkan kompetensi profesional yang dimiliki setelah selesai workshop. Tanggapan guru terhadap pelaksanaan kegiatan adalah positif dan sangat menguntungkan bagi guru-guru. Santoso dkk (2015) dalam pengabdian pada masyarakat di Kecamatan Matesih menyimpulkan pengabdian yang dilaksanakan telah berhasil, dapat dilihat dari peserta yang sudah bisa menyusun RPP sesuai format Kurikulum 2013. Selain itu, hasil ini juga didukung oleh Supriyono dkk (2015) yang menyatakan setelah mengikuti pelatihan pembuatan website, para guru di SMP Muhammadiyah 1 Kartasura dan SMA Muhammadiyah 4 Kartasura sudah bisa memulai membuat website, peserta juga berpendapat kegiatan pelatihan sangat bermanfaat untuk meningkatkan kemampuan peserta dan berharap ada kegiatan lanjutan.

Dari pelaksanaan kegiatan pertemuan kedua tahap akhir ini telah dihasilkan perangkat pembelajaran tim sekolah (tim Lesson Study) yang siap untuk diimplementasikan pada saat tindakan $(d o)$ di kelas.

\section{Kesimpulan}

Berdasarkan hasil pelaksanaan kegiatan ini dapat disimpulkan hal-hal berikut: (1) Telah terbentuk kelompok-kelompok guru (kelompok Lesson Study), yang di dalamnya ada pengkajian pembelajaran secara kolaboratif dan berkelanjutan berlandaskan pada prinsip-prinsip kolegalitas dan mutual learning untuk membangun komunitas belajar melalui tahapan-tahapan plan-do-see. (2) Kemampuan guru dalam pengembangan perangkat pembelajaran, penguasaan konsep materi ajar, dan pengembangan instrument 
penilaian dapat meningkat melalui kegiatan plan pada tahapan Lesson Study yang dilaksanakan secara kolaboratif oleh Tim/ kelompok Lesson Study.(3) Berdasarkan hasil evaluasi, respon peserta terhadap pelaksanaan kegiatan secara keseluruhan sangat baik, peserta berharap ada tindak lanjut pelaksanaan kegiatan.

Saran yang dapat disampaikan terkait dengan kegiatan ini : guru-guru hendaknya terus termotivasi untuk mengembangkan diri melalui diklat-diklat/pelatihan sejenis sebagai bagian dari Pengembangan Keprofesian Berkelanjutan. Hasil-hasil pelatihan hendaknya terus ditindaklanjuti/ ada keberlanjutan di masing-masing sekolah.

\section{Persantunan}

Kegiatan pengabdian ini bisa berjalan tidak terlepas dari bantuan berbagai pihak. Oleh karena itu, penulis menyampaikan terimakasih kepada: 1) Universitas Muhammadiyah Surakarta yang telah mendanai pengabdian ini. 2) Tim Pengabdi, rekan-rekan sejawat, dan mahasiswa yang telah membantu berjalannya kegiatan. 3) Guru-Guru Matematika SMA/SMK Muhammadiyah Klaten yang telah berkenan menjadi peserta kegiatan.

\section{DAFTAR PUSTAKA}

Muamaroh. 2015. Pakom Aplikasi Cooperatif Learning untuk Pembelajaran Bahasa Inggris di SMA dan SMK Muhammadiyah se Surakarta. Warta, ISSN: 1410-9344. Vol 18, No 2, September 2015: 118-125

Mulyana, Slamet. 2007. Lesson Study. Makalah. Kuningan: LPMP-Jawa Barat.

Santoso, Joko, Rahmawati, Laili E, Muhroji. 2015. Pakom Pengembangan Rencana Pelaksanaan Pembelajaran Berdasarkan Kurikulum 2013 di PCM Kecamatan Matesih Karanganyar. Warta, ISSN:1410-9344. Vol 18, No 1, Maret 2015: 46-52

Sukirman. 2010. Upaya Meningkatkan Mutu Perkuliahan Pada Perguruan Tinggi Melalui Lesson Study. Makalah. UNY: Yogyakarta

Subadi, Tjipto., Khotimah, Rita P., dan Sutarni, Sri. 2012. Model Pembinaan Pendidik Profesional (Suatu Penelitian dengan Pendekatan Lesson Study pada Guru-Guru Sekolah Muhammadiyah Kabupaten Sukoharjo). Laporan Penelitian tidak diterbitkan, Penelitian Unggulan Perguruan Tinggi (PUPT) Tahun I, LPPM UMS.

2013. Model Pembinaan Pendidik Profesional (Suatu Penelitian dengan Pendekatan Lesson Study pada Guru-Guru Sekolah Muhammadiyah Kabupaten Sukoharjo). Laporan Penelitian tidak diterbitkan, Penelitian Unggulan Perguruan Tinggi (PUPT) Tahun II, LPPM UMS.

Supriyono, Heru, Sujalwo, Sapoetra, Adjie. 2015. Pelatihan Pengembangan Media Pembelajaran Berbasis Web Bagi Guru SMP dan SMA Muhammadiyah Kartasura. Warta, ISSN: 14109344. Vol 18, No 2. September 2015:98-109

Slamet HW, Khotimah, Rita P., 2010. Peningkatan Kompetensi Guru Sekolah Dasar Melalui Lesson Study. Warta, ISSN: 1410-9344. Vol. 13, No. 1, Maret 2010, hal 55 - 64

Undang-Undang Nomor 14 Tahun 2005 Tentang Guru dan Dosen 